\title{
12 Human Rights on the Road to Nowhere
}

\author{
Stephen Hopgood
}

For most of recorded human history, people have been concerned about what constitutes freedom, equality, fairness, and justice. In different eras, and different places, these ideas have had radically different answers. Any attempt to produce a grand historical account of what constitutes justice, for example, would have to deal with the many ways in which treating people justly has involved killing, torturing, enslaving, ostracizing, or exiling them. Human equality and human freedom were similarly dependent on either your identity or on any sins or crimes against gods or the social body for which you were deemed responsible. To talk of human rights as transhistorical phenomena only works, as a result, if we see them as moral (not empirical) claims, arguing that people have always had these rights in principle, whatever the reality. We have not created them; we have simply discovered them. Our forebears were either unenlightened or morally wrong. In this way, talk of empirical human rights cannot draw sustenance from the past except through reverse engineering. Some people historically may have held rights-like ideas, but "human rights" - rights that attach to all individuals on account of their simply being human - are one of our era's distinctive ideologies about right, fair and just treatment. They are reflective of a - perhaps the-defining feature of Western-style modernity: the emergence of the idea of rational, autonomous, self-governing individuals as the primary building blocks of political and social life and as the fundamental source of moral value. This shift has only happened in a serious way in the last two hundred or so years.

Because classic human rights are, in this sense, individual entitlements held against each other and against collective authorities, the emphasis in most arguments for rights is on the primacy of personal choice in terms of beliefs, commitments, lifestyle, and identity. This is captured in the idea of rights as trumps: winning cards in the game of life that individuals can play against any attempt to regulate, prohibit, mistreat, or disadvantage them in the name of broader social or political 
goals, or the interests of other people. ${ }^{1}$ Human rights make us all ends, not means, to paraphrase Kant. They carve out an inviolable and personalized private sphere. As such, they are integrally about a conception of the person who exists in some way prior to her social bonds, morally complete in and of herself. We need society to live in a practical sense, but this necessity is secondary in moral terms. That is, what has priority in a human rights world organized according to the classic conception of human rights are the lives and choices of individual human beings, not the degree to which the doctrines of nations, families, tribes, and gods are brought to life in the lives of those same individuals. Any theory of human rights that does not put this person first - that on principle (not as a lack, or oversight) allows discrimination or curtails personal choicecannot be said to be consistent with the core inner logic of classical human rights claims, either conceptually or in their dominant historical form. How could an advocate of human rights accept any form of discrimination, unequal treatment, or unequal moral status on principle? How could any human rights agreement include such principles? Equal moral worth - and, as a logical consequence, prima facie equal individual autonomy over personal choice - are the founding principles of human rights claims. If we look at the world around us today, we see this is still a radical, even heretical, claim to make in many if not most societies.

This classic conception is not, nor has it ever been, the only option. Many places have vibrant civil societies pushing for justice, fairness, and social change - just not in the language of individual human rights (much less the idea of personal trump cards). The normative underpinnings of rights are distinct in giving social and political supremacy to the interests and choices of individuals. The classic conception does tend, it is true, to marginalize other sorts of rights claims. Demands for social and economic rights, as well as cultural and collective rights (e.g., the right to national self-determination), have always been part of the general rights discourse, with social and economic rights increasingly prominent in our era. But these claims do not map easily onto the individualist logic of the classic conception. And so they raise a critical issue of priority: for believers in the classic conception, individual rights must always come first. The collective can only legitimately claim to trump the interests of the individual person for three reasons: to prevent harm to others, to ensure the survival of the community as a whole, and for the best interests of the individual concerned. Even then, the bar is set high, the action's legitimacy will be hotly contested, and the language

\footnotetext{
${ }^{1}$ The idea of rights as trumps is indelibly associated with the work of Ronald Dworkin.
} 
of rights will merely be temporarily suspended until the classic conception reasserts itself as the norm.

I'll suggest, in Section 1, that this classic conception has until now dominated the theory and politics of human rights, having all but monopolized rights thinking in the West. And it is Western power, for better or worse, that built the modern international system of which our current global norms and rules are integral parts. This reflects not a unified view in "the West," but a very specific sort of ideology that closely mirrors the broad needs and interests of the (middle-class) social forces that have outsize influence on life within Western societies. This raises an important question: If the momentum for globalizing human rights relies on the rights-sensitivity of growing middle classes in China and India, will these classes prove revolutionary or will they seek to support a narrower range of individual rights that mirror their interests? Section 2 considers this question, asking what implications any move to a post-Western world might have for the future of human rights in terms of state resistance. Section 3 looks at responses to human rights in terms of social ambivalence. Just as the middle classes are undergoing rapid change in Western societies, so the utility of human rights ideas as a legitimating ideology for those classes is under pressure in areas such as civil liberties and immigration.

Finally, I suggest that in this story we can see the structural limits to human rights-led progress. This has two elements. First, human rights do - as they are supposed to - strike at core aspects of sovereignty. But they have no means to make this demand for state compliance stick in the long run, beyond aiding and abetting the growth of internal and transnational forces that edge the state in that direction. The battle that must be won first is political and cultural, not legal, although these are interlinked struggles. A functioning and reasonably stable international system is a precondition for any form of generalized normative progress. Even then, there is much human rights law states can simply ignore, especially if they are powerful (the United States, China, Russia, India) or strategically important (Myanmar, Sudan, Uzbekistan, Egypt, Turkey).

Second, how effective social forces are, and their direction of travel, depends crucially on whether or not the middle class moves in a progressive direction. My hypothesis here is that, other things being equal, members of the middle classes by definition enjoy many social and economic opportunities without the need for human rights, and when they do not, they seek only those rights that will fill gaps in their own power. Chinese voters may demand more political rights over time, they may even be supportive of women's and LGBT rights, but they will not seek large-scale redistribution of their new wealth. Neither will the Indian 
middle class. They'll prefer to work on international issues such as human trafficking rather than see their own power and leverage dissipated. Whichever way you look at it, social and economic rights will always be more attractive for those currently without capital. A class struggle emerges between the purveyors of civil and political rights and those of social and economic rights, in other words.

\section{Human Rights as a Western-led Normative Project}

There is nothing inherently Western about ideas like rights, or their successor concept human rights. Any society or civilization could have developed similar ideas in theory. It is simply the case that it was in the West (meaning Europe, followed by its settler colonies) that this ubiquitous modern ideology came to fruition in the particular sense of becoming an important part of the legal and cultural fabric and of having real political consequences. Moreover, human rights are obviously not the only way to be moral. There is much in the doctrines of Islam, Judaism, Buddhism, Hinduism, and Christianity, for example, or in socialist demands for equality, or in conservative claims about the responsibilities of community, that is socially and morally valuable and/or progressive but which never mentions rights or human rights (often preferring the idea of "right" and its antithesis, "wrong"). The fact remains that it is human rights that have assumed the status of a modern orthodoxy at the level of international norms, succeeding Christianity in this aspiration to be universal. And the reason for this is that the dominant powers in the international system have until recently been Western liberaldemocratic (and Christian) powers - Western and Northern Europe, the United States and Canada, Australia and New Zealand, and even Latin America, where legal and political systems as well as cultural and social institutions have been heavily marked by European influence, beginning with Christianity. In the Latin American case, human rights have been extremely important, even if they were also systematically abused by governments for much of the latter part of the twentieth century.

In other words, as historically situated normative innovations, there is little doubt that the West is where we must locate the drive for institutions that embed human rights globally. This does not mean that only Westerners (however we define such a problematic term) can hold those ideas - such a claim would be ridiculous, absurd, immoral, and empirically and historically false. It does not mean that a majority of Westerners actually believe in these ideas or enact them, as the callous moral failure of European states and societies to do more for destitute Syrian refugees 
amply demonstrates. It does not mean that Western states are not guilty of breathtaking hypocrisy and despicable historical crimes. It simply means that the global impact of human rights in international politics in the post-1945 era is explained mostly by specifically liberal social modernization efforts (e.g., democratization) that Western states have through their greater relative power attempted to globalize, especially since the 1970s. Not always, of course, but predominantly. Even if the expansion of human rights claims in the postwar period owes a great deal to innovations in the Global South, especially in former colonies, it is at the point that they were prioritized by Western states, and particularly the United States, that they became a significant feature of the international political system. Rights arguments were not enough. Power was essential. ${ }^{2}$ These human rights were not necessarily adopted as aspects of Western foreign policies for human rights reasons: the spread of a particular kind of liberal individualism is just as much the ideology of hegemonic forms of capitalism emanating from the West as it is of any genuinely moral urge. It also does not mean that human rights and the institutional manifestations to which they give rise cannot, once established, be owned, changed, claimed, and otherwise used outside the West. It is simply a claim about their political origins and institutionalization thus far. Indeed, we may be living through the change and it is to the possible implications of that change I want to draw attention.

Major human rights innovations show this influence. Where are the major institutions of the international human rights regime? Geneva, The Hague, New York. Where are the major global human rights NGOs? Add London and Washington to the list. The UDHR may have had a remarkable array of states and individuals inputting into it, and it does reflect a much broader array of rights - social and economic as well as civil and political - than the classic conception. But who were its primary drafters? Rene Cassin, Eleanor Roosevelt, Charles Malik (a Lebanese Christian and Heidegger student whose commitment to the dignity of the individual was anchored in his religious faith), and John Humphrey, a Canadian international civil servant. ${ }^{3}$ Where have regional human rights conventions and courts been most influential? Europe and the Americas.

${ }^{2}$ On the importance of the Global South in the emergence of human rights ideas after 1945, see Steven L. B. Jensen, The Making of International Human Rights; The 1960s, Decolonization, and the Reconstruction of Global Values (New York: Cambridge University Press, 2016).

${ }^{3}$ For an excellent discussion of Malik and an assessment of the claim he was a Westernized liberal, see Joe Hoover, "Remembering Charles H. Malik," (February 2011), at: http:// thedisorderofthings.com/2011/02/09/remembering-charles-h-malik/. 
Western Europe is routinely behind the Human Rights Council's strongest resolutions and is now the main funder of the International Criminal Court. ${ }^{4}$ Of the P5, only the UK and France have ratified the Rome Statute. The United States, while ambivalent about the ICC, has been consistently committed (at least, in principle) to the Universal Declaration of Human Rights. ${ }^{5}$ Which states took up the landmines treaty, or the Arms Trade Treaty, the ICC, and R2P? How many Asian or Middle Eastern states are members of the ICC? What is Africa's relationship with the ICC like? Who stands most squarely behind R2P? We can even see the West more narrowly, as Europe with Canada and the unpredictable engagement of the United States (sympathetic in principle, at least pre-Trump, conflicted in practice). Which countries in the Human Rights Council routinely lead resistance to the demands of Russia and China? European states. Who has pushed hardest for an international criminal investigation in Sri Lanka, or in North Korea? Europe and the United States. This normative architecture has been constructed under the hegemony of the West however much (or little) buy-in there has been from other states.

These rights are generally in sympathy with the political cultures of the modernizing industrial societies from which they emerged, and have been part of Western liberal discourse in broad terms dating back to the idea of natural rights (the clearest precursors to human rights). Indeed, they have come to dominate liberal discourse, relegating the utilitarian strain of liberalism culturally (if not practically) to marginal status. Human rights are not the only progressive doctrine that aims to combat injustice, nor were all the founders of human rights ideas Western. But from the UDHR onward, and especially since the 1970s, there has been a Western-led drive to globalize them for ideological and Realpolitik reasons.

It is important to note that human rights claims, while seeming to be merely political, in fact have deeper philosophical roots. There is a clear

${ }^{4}$ Stuart Ford, "How Leadership in International Criminal Law Is Shifting from the US to Europe and Asia: An Analysis of Spending on and Contributions to International Criminal Courts," Saint Louis University Law fournal vol. 55 (2010): 953-1000.

5 "Remarks by President Obama in address to the United Nations General Assembly, September 24, 2014," at: www.whitehouse.gov/the-press-office/2014/09/24/remarkspresident-obama-address-united-nations-general-assembly. In this speech, it is noteworthy, however, that while President Obama mentioned "human rights" twice, he did so by referring to the UDHR once and then by quoting Eleanor Roosevelt. At no point did he directly reference his commitment, nor that of US foreign policy, to protect and promote "human rights" per se. Indeed, in mentioning the UDHR he characterized its mission, along with that of the UN as a whole, as "the notion that peace is not merely the absence of war, but the presence of a better life." This is a statement of such generality no one could object. It is doubtful any statement even of this sort will be forthcoming from President Trump. 
conception of the person underlying them. Thus, at the heart of Westernstyle modernity lies what Macpherson called "the possessive individual." 6 The moral superiority of claims to children's, women's, and LGBT rights is self-evident on this view and any social, cultural, or political norm that doesn't respect the fully autonomous individual must, again on this view, be regarded as wrong. That's the bottom line. The veil? Female genital mutilation (FGM)? Unspeakable wrongs, from the perspective of human rights. It is obvious to advocates that any choice to wear the veil or facilitate FGM is simply a coerced choice, shaped by structures of patriarchy that have been so deeply embedded in culture they have led to a form of false socialization that disguises the reality of human moral equality.

Eliminating discriminatory practices of this sort was once called enlightenment and civilization. In our era, it is also often about capabilities and nudging. ${ }^{7}$ What argument to defend gender discrimination on principle could be made by any opponent of human rights and expect to be taken seriously? For human rights advocates, defending gender discrimination on principle is like defending racism on principle. In a world where human rights prescribes the limits of legitimate discourse, there is no longer any language in which to do it. These are red lines. Human rights are not a road to nowhere for their most ardent advocates, they are an often meandering and frustrating, sometimes slower, sometimes quicker journey toward a clear and predetermined moral destination. That destination is the legal right and social capacity, based on natural human moral equality, to make fully informed autonomous life choices as individuals.

This major historical shift is broadly in line with substantive moral norms within Western societies. The free societies in Freedom House's 2015 annual report are overwhelmingly in the West. The focus of global human rights is in areas such as the ICC, R2P, crimes against humanity, a world court of human rights, that place civil and political, justice and protection institutions first. The majority of research on human rights focuses on mental and bodily integrity - civil and political rights - as well. This is neither contingent nor accidental. These are the rights which work in alliance with the underlying distribution of social and economic power worldwide. The social classes who have the money or the political power - the leverage - to change things only need be

${ }^{6}$ C.B. Macpherson, The Political Theory of Possessive Individualism: Hobbes to Locke (Oxford: Clarendon Press, 1962).

7 Martha C. Nussbaum, "Symposium on Amartya Sen's Philosophy: 5 Adaptive Preferences and Women's Options," Economics and Philosophy 17 (2001) and Richard $\mathrm{H}$ Thaler and Cass R Sunstein, Nudge: Improving Decisions About Health, Wealth and Happiness (New York: Penguin Books, 2009). 
interested in the civil and political rights part of the equation. They want a voice for themselves domestically and a voice with their like-minded class compatriots internationally. They don't need to worry about social and economic rights because they can produce and consume in the private sector, which gives them access to all the goods and services they need.

As for cultural rights, I would argue these are essentially incomprehensible within the mainstream global human rights regime (hence the lack of attention they receive). They are anathema to individual rights, frequently the problem not the solution, and even if they can be made conceptually coherent, they must still be anchored in the final analysis on individual claims and entitlements, and so they are always trumped by individual rights. The same is broadly true for group rights claims as well. As Samuel Moyn has argued, the classic group right - to national selfdetermination - was largely killed off by the switch in the 1970s toward the classical conception of civil and political rights. ${ }^{8}$ That this coincided with the uptake by Western middle classes and governments of human rights ideas is not incidental. This is why human rights research has discovered that human rights are best observed in the places that need them least. ${ }^{9}$ In rights-observing societies, the public/private split and the primacy in principle of the individual, the distinctive features of modern liberalism, are marked. These are constitutively liberal spaces. ${ }^{10}$ And they have exported and institutionalized that liberalism.

There is evidence, however, that these liberal, mainly European, states are losing influence in organizations such as the United Nations that they still do so much to fund. ${ }^{11}$ Leaving aside the ongoing problems associated with the Euro after 2008, and fallout from Brexit and the election of Donald Trump, decreases in European defense spending represent a trend dating back to the end of the Cold War (as a share of GDP, for

${ }^{8}$ Samuel Moyn, The Last Utopia: Human Rights in History (Boston: Harvard/Belknap Press, 2010).

9 Emilie Hafner-Burton, Making Human Rights a Reality (New Jersey: Princeton University Press, 2013).

${ }^{10}$ The metaphysical basis for this political ideology is too large a subject for analysis here; suffice it to say that the urge to rid justice of its political foundations to enhance legitimacy must co-exist with the reality that it is only as a political compromise that documents such as the Universal Declaration of Human Rights gained assent in the first place. See Joshua Cohen, "Minimalism about Human Rights: The Most we can Hope For?" Fournal of Political Philosophy 12, no. 2 (2004), and on the problematic nature of the classic "human rights as moral rights" story, see Joseph Raz, "Human Rights without Foundations," Oxford Legal Studies Research Paper 14 (2007).

${ }^{11}$ See Richard Gowan, "Who Is Winning on Human Rights at the UN?" European Council on Foreign Relations, September 2012; and Richard Gowan and Franziska Brantner, "The EU and Human Rights at the UN: 2011 Review," European Council on Foreign Relations, at: http://www.ecfr.eu/page/-/ECFR39_UN_UPDATE_2011_MEMO_AW.pdf. 
example, the UK's defense spending fell from 4.4 percent to 2.2 percent from 1989 to 2008, France's from 3.7 percent to 2.3 percent and Germany's from 2.9 percent to 1.3 percent). ${ }^{12}$ It was still falling in all three in $2014 .^{13}$ In a recent article in International Affairs, Douglas Webber argues that there is a clear decline in Europe's military and economic power, which has inevitably weakened its capacity to influence world events, as revealed starkly in Crimea (and Syria and Ukraine). In Syria, in particular, the evisceration of international humanitarian law by the Assad government and by Russia has been unchecked by European protest. Even though Europe's soft power retains potency, unbacked by hard power it will further lose effectiveness, Webber claims. ${ }^{14}$

Freedom House recently reported an eleventh successive year of declining freedom worldwide, civil liberties and political rights being the key variables it measures annually to make this assessment. ${ }^{15}$ Although until 2006 there had been three decades of increase in the number of democracies globally, the world has since then, argues Larry Diamond, entered a period of "democratic recession." "16 This recession has several aspects: more democratic breakdowns, declining quality of democracy in some pivotal states, deepening authoritarianism in others, and established democracies that "increasingly seem to be performing poorly and to lack the will and self-confidence to promote democracy effectively abroad."17 The United States is front and center when it comes to lack of will, according to Diamond. Not only are its own democratic structures underperforming, but it has lost the confidence or will internationally to pursue liberal reforms. This will surely only get worse under President Trump.

${ }^{12}$ Fabio Liberti, Defence Spending in Europe: Can We Do Better Without Spending More? (Notre Europe, 2001), 16, at: http://www.notre-europe.eu/media/policy46_fliberti_en .pdf?pdf $=$ ok.

13 The Economist, "Global defence spending," (February 2015), at: www.economist.com /news/economic-and-financial-indicators/21643167-global-defence-spending? $\mathrm{fsrc}=\mathrm{scn} /$ tw/te/ed/pe/globaldefencespending.

${ }^{14}$ Douglas Webber, "Declining Power Europe? The Evolution of the European Union's World Power in the Early 21 st Century," International Affairs 91, no. 2 (2015). See also Christopher Hill's discussion of the decline in importance of the UK and France globally: "Powers of a Kind: The Anomalous Position of France and the United Kingdom in World Politics," International Affairs 92, no. 2 (2016).

${ }^{15}$ Freedom House, "Freedom in the World 2017," at: https://freedomhouse.org/report/ freedom-world/freedom-world-2017.

${ }^{16}$ Larry Diamond, "Facing up to the Democratic Recession," Fournal of Democracy 26, no. 1 , January 2015.

${ }^{17}$ Diamond, "Facing up to the Democratic Recession," p. 144. Diamond distinguishes liberal democracies from electoral democracies, the former restricted to those scoring 1 or 2 on the Freedom House scale. In other words, to assess the state of democracy, rights and liberties, along with transparency and the rule of law, are central elements, confirming the link between rights and democracy. 
Indeed, even before Trump, the United States, the engine for Western influence after 1945, was itself unsure about its strategic direction. It now faces more competition than it has since the 1980s from global rivals. ${ }^{18}$ Attempts to shift its strategic focus to Asia have meant demanding more "burden sharing" from Europeans (and others). ${ }^{19}$ This is a relative not absolute decline. If we take as the measure of economic power per capita GDP, not the absolute size of the economy, the United States is hugely ahead of China, as well as dwarfing all other powers in terms of its military spending. ${ }^{20}$ According to The Economist, the United States in 2014 spent $\$ 581$ billion on defense, compared with second-placed China at $\$ 129$ billion. ${ }^{21}$ But this was a decline in US defense spending. In Saudi Arabia spending went up by 21 percent, followed by China (up 9.7 percent) and Russia (up 8.3 percent). Russia spends more of its GDP per capita on defense than the United States, the US's share of global defense spending having fallen from 47 percent in 2010 to 38 percent in 2014 .

This would seem to be consistent with the broader feelings of many Americans. After Iraq and Afghanistan, record numbers now say they want the United States to let other countries get on with their own business with less US intervention, "shared leadership" being a better model for them than hegemony. ${ }^{22}$ And one of President Trump's key campaign promises was to put the national interests of the United States above any other consideration. This is troubling because on key human rights issues, it is often American diplomatic involvement that makes the difference - Sri Lankan war crimes investigations and action to prevent global anti-blasphemy laws just two recent examples. ${ }^{23}$ It is difficult to

${ }^{18}$ On the decline or otherwise of American power, see Christopher Layne, "The Waning of U.S. Hegemony - Myth or Reality? A Review Essay," International Security 34, no. 1 (2009). See also Robert J. Lieber, Power and Willpower in the American Future: Why the United States Is Not Destined to Decline (New York: Cambridge University Press, 2012); Robert Kagan, "Not Fade Away: The Myth of American Decline," National Review, January 2012; Robert D. Kaplan, Monsoon: The Indian Ocean and the Future of American Power (New York: Random House, 2010); Fareed Zakaria, The Post-American World (New York: W. W. Norton, 2009).

19 "Remarks by President Obama in Address to the United Nations General Assembly," September 24, 2013.

20 Robert J Lieber, "The rise of the BRICS and American primacy," International Politics, pp. 1-18, 2014.

21 The Economist, "Global defence spending," (February 2015).

${ }^{22}$ Pew Research Center, "Americans: Disengaged, feeling less respected, but still see US as world's military superpower," at: www.pewresearch.org/fact-tank/2014/04/01/americansdisengaged-feeling-less-respected-but-still-see-u-s-as-worlds-military-superpower/.

${ }^{23}$ Ronak D. Desai, "Tensions rise between the United States and Sri Lanka over human rights," Huff Post Politics, April 28, 2014: www.huffingtonpost.com/ronak-d-desai/a-rowemerges_b_4859375.html; Nina Shea, "An anti-blasphemy measure laid to rest," National Review, March 31, 2011: www.nationalreview.com/article/263450/antiblasphemy-measure-laid-rest-nina-shea. 
imagine coordinated action against ISIS without the United States as the principal military and diplomatic leader, for example.

\section{Human Rights in a Post-Western World}

In any post-Western world, should that emerge, Western states, particularly Europe - if it remains united - and most obviously the United States, will remain highly influential. Post-Western means more precisely post-Western hegemony. The West simply will not remain as influential. How could it, with the rise of China, India, Brazil, and Indonesia, to give just four examples? China's strategic position on the Security Council, for instance, gives it great leverage and has perhaps even emboldened Russia in pursuing a more confrontational foreign policy (e.g., over Syria). Given that there are major problems with human rights compliance even though Western states have dominated the international system for more than a century, it is not a stretch to hypothesize that this situation is only likely to get worse.

If Europe does decline in influence, this will only reveal the degree to which "the West" has been disproportionately dependent on American power. Certainly from the end of the Cold War to maybe the invasion of Iraq in 2003, it made sense to speak of world politics as unipolar, and of the United States as enjoying a "unipolar moment." 24 What we are experiencing now is a shift away from that toward either bipolarity or a qualified sort of multipolarity. ${ }^{25}$ What might the implications of such a shift be? If the gap in power is big enough, the hegemon - or, under bipolarity, the major powers - have latitude for more expansive foreign policies. They can, in brief, afford to spend diplomatic capital on issues such as human rights which are not primary to national security. As the gap narrows, and as power comes to be in shorter supply, it must be reserved for vital interests and it is rare, aspirational rhetoric apart, that threats to human rights elsewhere represent threats to national security. Moreover, as dominant powers lose influence, that power is being dispersed to others (otherwise major powers would retain their relative advantage). Other things being equal, some medium-sized and even small powers might now drive a harder bargain for being an alliance member or refraining from joining a rival grouping. Thus, the shift to multipolarity may usher in a world where diverse norms buck the trend to isomorphism. ${ }^{26}$ Think Central Asia and ASEAN.

${ }^{24}$ William Wohlforth, "The Stability of a Unipolar World," International Security 24, no. 1 (1999): 5-41.

25 Or, in Richard Haass's view, "nonpolarity." See Haass, "The Age of Nonpolarity: What Will Follow US Dominance?" in Foreign Affairs (May/June 2008).

${ }^{26}$ Peter J Katzenstein (ed) The Culture of National Security: Norms and Identity in World Politics (New York: Columbia University Press, 1996), and John Boli and 
For example, at a February 2015 White House conference on combatting violent extremism, President Obama's invited audience included the Egyptian foreign minister and the prosecutor general of Kazakhstan. Other attendees included officials from Bahrain, Saudi Arabia, and Uganda. The president stressed the importance of democracy and freedom in defeating terrorism, but the conference in reality highlighted the need for the US to get cooperation from governments that a Human Rights First spokesperson described as "part of the problem." ${ }^{27}$ Human Rights Watch's chief, Kenneth Roth, called the president "Obama the disappointment." 28 In a multipolar world, these are new realities, and poor human rights compliance is not a deal breaker. It is not the $1980 \mathrm{~s}$, or indeed the 1990s (when US power was preponderant). The narrow selfinterested focus of President Trump's foreign policy aims will likely seriously exacerbate this drift. His admiration for authoritarian leaders just compounds the problem.

Do global norms need a backer of last resort? Neorealists and many neoliberals have always thought so. Charles Kupchan says of the future that it will be No One's World. China, as well as India, Russia, and Brazil, will challenge rules and institutions that do not meet their interests. ${ }^{29}$ There is no reason why mutual interests cannot be realized through norms in such a world. The question is whether a global liberal normative regime will be conceived of as mutually beneficial by a sufficient number of major powers. Customary international law is based on state practice, suggesting that if state practice changes - and sovereignty over the treatment of one's own citizens in opposition to R2P is re-affirmed - then customary international law will have turned away from human rights. Human rights advocates will argue this is just bad law, or no law at all. ${ }^{30}$ But is it? The breaking of a customary norm is also potentially the beginning of a new norm. ${ }^{31}$ In other words, it is only an assumption

George M Thomas (eds) Constructing World Culture (California: Stanford University Press, 1999).

27 Peter Baker and Julie Hirschfeld Davis, “On Terror, Gentle Hand or Iron Fist," New York Times (February 2015), at: www.nytimes.com/2015/02/20/world/obama-extremismsummit.html?emc=edit_th_20150220\&nl=todaysheadlines\&nlid=18548227\&_r=0.

${ }^{28}$ Kenneth Roth, "Obama the Disappointment," Human Rights Watch March 4, 2014, at: www.hrw.org/news/2014/03/03/obama-disappointment.

${ }^{29}$ Charles A. Kupchan, No One's World: The West, the Rising Rest and the Coming Global Turn (Oxford: Oxford University Press, 2012).

${ }^{30}$ Bringing to mind the Hart-Fuller debate of 1958 on whether law to be law must have progressive content in the broadly Kantian sense of morality. Lon L. Fuller, "Positivism and Fidelity to Law: A Reply to Professor Hart," Harvard Law Review 71, no. 4 (1958): 636. H.L.A. Hart, "Positivism and the Separation of Law and Morals,"Harvard Law Review 71, no. 4 (1958): 599.

31 Anthony D'Amato, The Concept of Custom in International Law. (Ithaca: Cornell University Press, 1971), p. 97. 
underwritten by liberal teleology that after more than a century of humanitarian and human rights law, customary international law is permanently about protecting individuals from harm, whether as civilians in war or as regular citizens.

John Ikenberry in Liberal Leviathan is more optimistic than Kupchan. Because rules and institutions are a more cost effective way of using material power to prevail, China will eventually accept the international order and work within it, he argues, the US-led international system's relatively open nature making it possible to accommodate such a vast new rising power. ${ }^{32}$ Rule-based orders are more legitimate than non-rulebased ones, Ikenberry says, and therefore easier and cheaper to control because they operate on the basis of consent rather than coercion. But here the word "liberal" has a very narrow remit. It means support for institutions that foster cooperation on issues such as trade, security, and arms proliferation, not support for broader norms about human rights (or potentially even democracy). For expansive liberalism, the end of Western hegemony means no one state or group of states can offer sufficient incentives or punishments to ensure compliance on issues that are not vital interests. ${ }^{33}$ In the American case specifically, US-China strategic competition is likely to be more central to US foreign policy than human rights concerns about South East Asian states like Vietnam and Thailand and even Myanmar, whose support is key to the strategy of containing China.

One model for a world of diverse norms, where human rights are less dominant, is legal pluralism - that is, co-existent legal regimes. This raises the "red line" question. Negotiated compromises on the basis of the interpretation of doctrine are one thing. Sources of agreement with human rights-like sentiments can be found in major religious texts and cultural traditions. But it cannot be the case that for human rights advocates the conversation with religions and cultural rights, even with social and economic rights, has no red lines in everyday social life. If there are no such inviolable borders, how are disputes between traditional and human rights authorities to be reconciled? In favor of the status quo? This would privilege all sorts of rights-violating norms: e.g., FGM, rape in marriage, violence against LGBT people. Of course, FGM must end, like the veil must go and domestic violence must cease. If, that is, the classic conception is to be realized. It seems to be an open-ended conversation, but it is not. For activists this is very definitely the road to somewhere. At most,

${ }^{32}$ G. John Ikenberry, Liberal Leviathan (Princeton: Princeton University Press, 2011). pp. 345-7.

${ }^{33}$ See, for a counter view, Hafner-Burton, Making Human Rights a Reality. 
a few mildly pragmatic compromises might be made - using subtler means such as two-speed processes, nudges and gentle persuasion, and education programs, to improve human rights outcomes. But the principles at issue, the ends to be pursued, are in no sense negotiable - the priority of the individual as a self-conscious and independent moral person is the very foundation of the human rights project.

But this clear view of what human rights are is less and less consensual. Pointing to the law only takes us so far in a world of ambiguous compliance. What human rights entail is contested by governments and within societies. Even when public opinion as a whole is in favor of human rights, this tells us little about specific cases. One example is in areas where a counter-claim in the language of rights can be made, such as the rights of the unborn child - that is, the right to life - versus reproductive rights. Another is between property rights and equality rights. A third is where different kinds of freedom rights clash - between free expression and minority rights in areas like religious freedom, for example. In these cases, people on both sides try to play their trump cards. Then there is a more pernicious form of rights deployment that flourishes when the opponents of change use the language of rights to defend and promote practices that are not consistent with the basic idea of individual rights underlying the classic conception. In some cases, rights are even used to defend illiberal causes. ${ }^{34}$

ASEAN, for example, passed a human rights declaration which local human rights groups condemned as an "anti-human rights declaration." 35 China's response to the UN's 2014 report on North Korea, which recorded "unspeakable atrocities," was: "Of course we cannot accept this unreasonable criticism. We believe that politicizing human rights issues is not conducive towards improving a country's human rights. We believe that taking human rights issues to the International Criminal Court is not helpful to improving a country's human rights situation." 36

In 2012, Russia promoted and passed a resolution on traditional values at the Human Rights Council, which put forward in the name of human rights notions about nation and family that are clearly at odds with the classic conception of human rights in that they deny individuals their veto over authority (the Russian Orthodox Church's position on human rights

${ }^{34}$ Cliff Bob, The Global Right Wing and the Clash of World Politics (Cambridge: Cambridge University Press, 2012).

${ }^{35}$ Human Rights Watch, "Civil Society Denounces Adoption of Flawed ASEAN Human Rights Declaration," at: www.hrw.org/news/2012/11/19/civil-society-denouncesadoption-flawed-asean-human-rights-declaration.

${ }^{36}$ Reuters, "China Rejects UN Criticism in North Korea Report, No Comment on Veto," February 18, 2014, available at: www.reuters.com/article/2014/02/18/us-china-koreanorth-idUSBREA1H0E220140218. 
mirrors this resolution). ${ }^{37}$ Norway's Helsinki Committee says of the Russian resolution:

During recent years, a Russian-sponsored initiative at the UN Human Rights Council has been targeting core tenets of international human rights: their universality, their unconditional nature, and their challenge to traditions that uphold discrimination and intolerance. The proponents of the initiative have camouflaged it as laying out new ways of promoting human rights. Traditional values of humankind are a tool to strengthen and underpin human rights at the local level, they claim. In reality, the initiative threatens to destroy consensus among the states of the world on how they should honor their human rights obligations. ${ }^{38}$

But the elasticity of rights concepts and the interpretability of rights claims, let alone the caveats that exist even in UDHR Article 29 about "morality, public order and the general welfare in democratic societies," facilitate such a challenge to the previously hegemonic understanding of rights. Politically speaking, human rights norms are now "essentially contested concepts" where the phrases "this is a human right" and "human rights give rise to the following binding obligations" are not just disagreements about how a concept is properly used but about what the concept entails in a more foundational sense. ${ }^{39}$ The resolution of these struggles at the international level is not to be found in discursive interaction but in the political leveragethe power - alliances can muster in global institutions. As power is increasingly dispersed, the chances of forging a global consensus recede. This is, I would argue, the coming human rights future.

The extreme version of politicization manifests itself most strongly in the cases of China and Russia. Rather than find ways to accommodate rights, they have both set themselves up broadly in opposition to the global human rights regime. ${ }^{40}$ In the Russian case, this has led to active hostility toward human rights as a whole, and foreign-funded human rights groups in particular. ${ }^{41}$ Even when China has used human rights language, it does so in ways that emphasize social and economic over civil and political rights, and which stress sovereignty and national

${ }^{37}$ See, for example, Cai Wilkinson, "Putting "Traditional Values" into Practice: The Rise and Contestation of Anti-homopropaganda Laws in Russia," Fournal of Human Rights 13 (2014): 363-79.

${ }^{38}$ Norwegian Helsinki Committee, "Russia's Traditional Values Initiative Result [sic] in Abuse at Domestic Level," June 20, 2014, at: http://nhc.no/no/nyheter/Russia's +traditional+values+initiative+result+in+abuse+at+domestic+level.b7C_wlnKY2.ips.

39 W B Gallie, "Essentially Contested Concepts," Proceedings of the Aristotelian Society, vol. 56 (1955), pp. 167-98.

40 In "Facing up to the Democratic Recession," Diamond describes Russian-Chinese collaboration within the Shanghai Cooperation Organization as an "axis of cynical cooperation," p. 151.

41 Tanya Lokshina, "Russia's Backward Roll," Human Rights Watch (July 2014), at: www .hrw.org/news/2014/07/30/russias-backward-roll. 
self-determination. It is also adept at exposing Western hypocrisy by producing reports that identify human rights abuses in the West. ${ }^{42}$ All of which does little for the legal protections that individual rights are meant to provide. In other words, human rights language might be acceptable where it is diluted of all significance, and resisted or ignored where it might still carry weight. ${ }^{43}$

Moving away from unipolarity, and from the hegemony of Western power, opens up space for alternative international norms. China and Russia have led the way in diffusing strategies and mechanisms by which to institutionalize authoritarian rule more effectively. ${ }^{44}$ This creates room, especially in terms of legitimacy, for the new authoritarians to counter human rights, whether through rejection, evasion, or cooptation. To see this as merely a transient phenomenon, we would have to believe that Russia and China will at some point reverse themselves and embrace human rights norms at the international level. But the authoritarian toolkit they are exporting will blunt domestic capacity building further, thus making it even harder for rights advocates to make an impression on powerful, illiberal governments.

There are many obvious forms of pushback by states, such as the use of increasingly coercive methods to suppress dissent in Egypt, Turkey, Bahrain, Thailand, Vietnam, Pakistan, Venezuela, the Philippines, and Saudi Arabia, to name just a few cases. These methods are endemic in Central Asia and parts of the Middle East, as well as throughout many parts of Africa. Freedom House describes this as "the twilight of modern authoritarianism," arguing that the semblance of concessions (e.g., pluralistic media, political competition, rule of law) that anti-democratic regimes made for several years around the turn of the century - while the impact of unipolarity could still be felt - has now dropped away and full authoritarianism is returning. ${ }^{45}$ Freedom House's 2015 report which marked this shift - was titled "Return to the Iron Fist." ${ }^{46}$ With

42 Xiaoyu Pu, "Can China be a Normative Power?” OpenGlobalRights ((June 2013) at: www .opendemocracy.net/openglobalrights/xiaoyu-pu/can-china-be-normative-power.

43 Tianzhao Yang and Jiangnan Zhu, "Collective Apathy: Nationalism and Human Rights in China," OpenGlobalRights (March 2014) at: www.opendemocracy.net/openglobal rights/tianzhao-yang-jiangnan-zhu/collective-apathy-nationalism-and-human-rights-inchina. Yang and Zhu suggest China might be more supportive of a language like "the efficient administration of justice" rather than human rights.

44 Diamond, "Facing up to the Democratic Recession," p. 152.

45 Tyler Roylance, "The Twilight of Modern Authoritarianism," Freedom House (October 2014), at: https://freedomhouse.org/blog/twilight-modern-authoritarianism\# .VG7vnIfZfdk

46 Freedom House, Discarding Democracy: Return to the Iron Fist (2015), at: www .freedomhouse.org/sites/default/files/01152015_FIW_2015_final.pdf. 
President Trump's labeling of the American press as an "enemy of the people," authoritarianism has reached a new level of intensity.

More subtle methods can also be used, to control rather than suppress human rights activism. For example, manipulating funds is a strategy for resistors. Former United Nations human rights commissioner, Navi Pillay, warned in 2013 that human rights budgets were not keeping up with needs - the flow of money to finance wider human rights surveillance an obvious weak point in a world where the West no longer wants to pay. ${ }^{47}$ India and Russia, to take two cases, also use laws on foreign donors to restrict flows of money to indigenous human rights NGOs. They can easily adopt similar policies internationally to control donations to organizations that propagate causes with which they disagree, and they will not be alone in doing so. In other cases, such as Egypt, denying visas to major human rights figures is another strategy. ${ }^{48}$

Western hypocrisy does not help. Hungary's "illiberal democracy" is an example from the Western bloc where state authoritarianism is growing, while many see Australia's immigration policy as a violation of human rights. ${ }^{49}$ The Obama administration may have repudiated the Bush administration's interpretation of the applicability of the Convention Against Torture, but in the case of extraterritoriality and cruel, inhumane, or degrading treatment, the president was reluctant, despite the advice of State Department lawyers, to repeal Bush's interpretation in all cases. ${ }^{50}$ President Obama was adept at lawfare himself when it came to issues such as targeted killing and Guantanamo. ${ }^{51}$ And President Trump has openly advocated a return to torture, despite the opposition of his Defense Secretary (whose view, the new president says, he will

${ }^{47}$ OHCHR Report 2012, at: www2.ohchr.org/english/ohchrreport2012/web_en/pages/int roduction.html

${ }^{48}$ Reuters, "Human Rights Watch Staff Denied Entry to Egypt," The Guardian (August 2014), at: www.theguardian.com/world/2014/aug/11/human-rights-watch-staff-egypt.

${ }^{49}$ Kati Marton, "Hungary's Authoritarian Descent," New York Times (Nov. 2014), at: www.nytimes.com/2014/11/04/opinion/hungarys-authoritarian-descent.html?_r=2, and Helen Davidson and Ben Doherty, "Australia's 'Abusive Refugee Policies' Criticized in Damning International Report," The Guardian (January 2016), at: www .theguardian.com/law/2016/jan/27/australias-abusive-refugee-policies-criticised-in-da mning-international-report.

50 Jack Goldsmith, "The debate about the extraterritorial scope of the torture Convention's provisions on cruelty is (almost certainly) not about USG interrogation policy," Lawfare, October 24, 2014, at: www.lawfareblog.com/2014/10/the-debate-about-theextraterritorial-scope-of-the-torture-conventions-provisions-on-cruelty-is-almost-cer tainly-not-about-usg-interrogation-policy/.

${ }^{51}$ Jo Becker and Scott Shane, "Secret 'Kill List' Proves a Test of Obama's Principles and Will," International New York Times, May 29, 2012: www.nytimes.com/2012/05/29/world/ obamas-leadership-in-war-on-al-qaeda.html?emc=eta 1 . 
respect). ${ }^{52}$ In the UK case, the president of Kenya, Uhuru Kenyatta, previously indicted by the ICC for crimes against humanity, cited the British government's ambivalence about human rights as evidence that the whole human rights regime itself lacks legitimacy. ${ }^{53}$ The ISIS fighters holding hostages in Syria dressed their captives in Guantanamo-style orange jumpsuits and water-boarded American hostage James Foley before beheading him. ${ }^{54}$

The use by the United States and the United Kingdom of massively intrusive surveillance is a further sign that authoritarian government is not confined to the non-West. Control of cyber-space is an issue where China and Russia have led the way, followed by a whole range of other states who fear this tool of open communication and dissent. But the response of the American and British governments - to preach open internet communications while collecting masses of data on their own and foreign citizens without oversight - seems to many an egregious example of hypocrisy.

\section{Social Ambivalence}

The picture I have drawn so far might suggest that pro-human rights populations are trapped inside illiberal sovereign containers, particularly outside the West. But the story at the social level is more complex than that. Human rights have always been a problem for both the left and the right. ${ }^{55}$ Marx argued in On the fewish Question in 1844 that political freedom was a poor substitute for economic freedom. Critics of major international interventions - especially Kosovo, but also Libya - have seen human rights as the vanguard of a new kind of NATO-led Western imperialism. ${ }^{56}$ Resistance from the right comes from advocates of

52 Kristina Wong, "Mattis still opposes torture despite Trump comment," The Hill (January 2017), at: http://thehill.com/policy/defense/316356-mattis-remains-opposed-to-torturepentagon-says.

53 Adam Wagner, "Kenyan President uses Tory Human Rights Plans to Defend was Crimes Charges," UK Human Rights Blog (October 2014), at: http://ukhumanrights blog.com/2014/10/24/kenyan-president-uses-tory-human-rights-plans-to-defend-war -crimes-charges/.

${ }^{54}$ Rukmini Callimachi, "The Horror before the Beheadings," New York Times (October 2014), at: www.nytimes.com/2014/10/26/world/middleeast/horror-before-thebeheadings-what-isis-hostages-endured-in-syria.html.

${ }^{55}$ See, for example, Costas Douzinas. The End of Human Rights: Critical Legal Thought at the Turn of the Century (Oxford: Hart Publishing, 2000), and Stephen Holmes, The Anatomy of Antiliberalism (Cambridge, MA: Harvard University Press, 1996).

${ }^{56}$ Danilo Zolo, Invoking Humanity: War, Law, and Global Order (London: Continuum, 2002), Jean Bricmont, Humanitarian Imperialism: Using Human Rights to Sell War (New York: Monthly Review Press, 2007); Robin Blackburn (ed.), The Imperialism of Human Rights, New Left Review, special issue 234 (1999); Ray Kiely, "Intervention: Imperialism or human rights?" OpenDemocracy, October 20, 2014, at: www 
sovereignty and nationalism (the many right-of-center European and American politicians skeptical about immigration, for example) and also from those who see rights as a threat to traditional social values and as heralds of a more bureaucratized, rule-bound, and disenchanted world (e.g., Leo Strauss, Carl Schmitt). Rights here are seen as constraining national community, power, and mission, as undermining the traditional, embedded, and specific norms and customs that give a nation a unique identity over time. Nations become soft, engineered, bland, and weak, the rule of law overwhelms the rule of men, and manifest destiny evaporates in a cloud of bureaucracy, constraint, and mediocrity. ${ }^{57}$ One obvious contemporary example comes from the United Kingdom, where a particular kind of anti-immigration nationalist sentiment has taken hold (fueling Brexit), pushing right-wing politicians to advocate rejection of the European Court of Human Rights (for putting rights before public order and national security) and even to demand repeal of the United Kingdom's own Human Rights Act. ${ }^{58}$

There are other objections to human rights - the Catholic Church and the Muslim Brotherhood together contesting women's rights at the Commission on the Status of Women, for example. ${ }^{59}$ In terms of LGBT rights, recent setbacks in India, Jamaica, and particularly Uganda (and increasingly throughout Sub-Saharan Africa), let alone in Russia, show how little impact decades of human rights work has made to nondiscrimination on the basis of sexuality. ${ }^{60}$ Pope Francis has been savvy about counter-posing poverty and abortion and asking which should be the priority (while making more liberal gestures toward the role of women and LGBT people in religious life). ${ }^{61}$ The language of rights can also prove

.opendemocracy.net/ray-kiely/intervention-imperialism-or-human-rights. Slavoj Zizek, "Against Human Rights," New Left Review 34 (2005), pp. 115-31.

${ }^{57}$ Holmes, The Anatomy of Antiliberalism.

${ }^{58}$ Jon Henley, "Why is the European Court of Human Rights Hated by the UK Right?" The Guardian (Dec 2013), at: www.theguardian.com/law/2013/dec/22/britain-european -court-human-rights. The strategy document in which any future Conservative government promises to scrap the UK's Human Rights Act is available here: www.theguardian .com/politics/interactive/2014/oct/03/conservatives-human-rights-act-full-document.

${ }^{59}$ Jill Filipovic, "UN Commission on the Status of Women Unmasks the Enemies of Equality," The Guardian, March 18, 2013:, at www.theguardian.com/commentisfree/ 2013/mar/18/un-commission-status-women-enemies-equality.

${ }^{60}$ Although for a more nuanced reading which problematizes the "Orientalist" divide this suggests between the civilized and uncivilized worlds, see Rahul Rao, "The Locations of Homophobia," London Review of International Law, vol. 2, no. 2 (2014): 169-99. In addition, the success of demands for same-sex marriage in the United States, despite conservative and religious resistance, suggests that LGBT rights might make progress where they are not seen as antithetical to core social values about the sanctity of marriage.

${ }^{61}$ Antonia Blumberg, "In his Speech to Congress, the Pope said 10 Times More about Poverty than Abortion," HuffPost Religion (September 2015), at: www.huffingtonpost .com/entry/pope-congress-poverty_us_56043b2be4b0fde8b0d1a71d. 
ineffective or even counterproductive, necessitating a different approach to achieving the desired end. In the case of anti-FGM campaigns in Africa, for instance, we see how a more pragmatic approach is bringing some hope for improvement, rather than the dogmatic attachment to condemnation in the language of human rights that has been more prevalent since the 1990s. ${ }^{62}$

Even when there is progress in situations where religious objections to human rights remain strong, this may not take place in the way global human rights advocates expect. Kevin Ward has shown, for example, that while the law on LGBT rights is more progressive in South Africa, the treatment of gay people is significantly worse there than in Uganda, where the law is more regressive. ${ }^{63}$

According to one recent report on Indonesia, meanwhile, even though abortion remains technically illegal, it is tolerated both socially and religiously (Islamic authorities being more progressive here than the Catholic Church in the nearby Philippines). ${ }^{64}$ But Indonesian politicians are loath to deal with the question formally, by changing the law, for fear that they will politicize the issue and thereby lose support (hardening positions and eroding the unspoken compromise that exists). Yet many of those who support this de facto pro-abortion status quo nevertheless do not want to advance what they call "Western values," a term connoting a loosening of public morals and validation for sexually uninhibited lifestyles. These are seen as a threat to norms of social propriety in Indonesia even though sexual and cultural freedom is a core element of human rights. ${ }^{65}$

Systematic data on social support for human rights is scarce, but global opinion polls certainly suggest there is widespread rhetorical enthusiasm for the idea of human rights. ${ }^{66}$ As the global middle class grows in an era

${ }^{62}$ UNICEF, "Female Genital Mutilation/Cutting: A Statistical Overview and Exploration of the Dynamics of Change," July 2013, at: www.unicef.org/media/files/FGCM_Lo_res .pdf; Gerry Mackie and John LeJeune, "Social Dynamics of Abandonment of Harmful Practices: A New Look at the Theory," UNICEF Innocenti Working Paper, 2008, available at: http://pages.ucsd.edu/ gmackie/documents/UNICEF.pdf.

${ }^{63}$ Kevin Ward, "Religious Institutions and Actors and Religious Attitudes to Homosexual Rights: South Africa and Uganda," in Corinne Lennox and Matthew Waites (eds.) Human Rights, Sexual Orientation and Gender Identity in the Commonwealth: Struggles for Decriminalisation and Change (London: School of Advanced Study, 2013), pp. 409-27.

${ }^{64}$ Tom Hundley, "Southeast Asia: 'A Certain Medical Procedure,"' Pulitzer Center on Crisis Reporting, February 12, 2014, available at: http://pulitzercenter.org/reporting/asiaphilippines-indonesia-abortion-underground-shame.

${ }^{65}$ Hundley, "Southeast Asia: 'A certain medical procedure."”

${ }^{66}$ World Public Opinion.Org, "Poll Finds Strong International Consensus on Human Rights," (Dec. 2011), at: http://worldpublicopinion.net/polls-find-strong-internationalconsensus-on-human-rights/. For more nuanced data, see James Ron, David Crow and Shannon Golden, "The Struggle for a Truly Grassroots Human Rights Movement," OpenGlobalRights (June 2013), at: www.opendemocracy.net/openglobalrights/james-ron -david-crow-shannon-golden/struggle-for-truly-grassroots-human-rights-move. 
of globalization, this support for liberal democracy would seem to mirror one of modernization theory's main assumptions - that liberalism (and therefore human rights) follows capitalism. In a classic of historical sociology, The Social Origins of Dictatorship and Democracy, Barrington Moore encapsulates this thesis in the phrase "No bourgeois, no democracy. ${ }^{\circ 7}$ It is the bourgeoisie - the town and city dwelling, commercially active middle classes - who advance democracy as a way to protect their property and person from state power and to promote their interests. This democratic struggle seeks three things: to check arbitrary rulers, to replace arbitrary rules with just and rational ones, and to "obtain a share for the underlying population in the making of rules." 68 These demands are at the heart of the human rights project.

But how interested are the middle classes (the new bourgeoisie) beyond acquiring basic civil and political rights? These narrow first-generation rights reinforce middle-class advantage, serving as both a constraint on elite power and on demands for redistribution from below (e.g., property rights). Western human rights supporters (not the more highly motivated activists and advocates) may be happy working on the rights of others overseas (on issues such as child rights and sex trafficking) and less keen on turning the human rights lens on what is happening within their own societies. This position is already to some degree mirrored by the rising middle classes of Asia and Africa. It is not good news for economic, social, and cultural rights. As Moore points out, those who provide support for the revolution, those who lead it, and those who benefit from it may be three separate sets of people. ${ }^{69}$ As he says, the price of a system that embeds bourgeois values may be "the perpetuation of a large amount of 'tolerable' abuse - which is mainly tolerable for those who profit by the system." 70

To take an obvious example, as Martin Gilens has shown, the top 20 percent of affluent Americans tend to be more liberal than the general population on religious and moral issues (including gay rights and abortion), but more conservative than the wider populace on tax, regulation, and welfare. ${ }^{71}$ Very wealthy Americans oppose redistribution of wealth or income by large margins. ${ }^{72}$ The one segment of this wealthy demographic that is slightly more in favor of regulation, environmental protection,

${ }^{67}$ Barrington Moore Jnr, The Social Origins of Dictatorship and Democracy (London: Penguin, 1966), p. 418.

${ }^{68}$ Ibid., p. $414 .{ }^{69}$ Ibid., p. $427 .{ }^{70}$ Ibid., p. 426.

${ }^{71}$ Martin Gilens, Affluence and Influence: Economic Inequality and Political Power in America (Princeton, NJ: Princeton University Press, 2012); also Benjamin I Page, Larry Bartels, and Jason Seawright, "Democracy and the Policy Preferences of Wealthy Americans," Perspectives on Politics, v. 11, no. 1 (2013): 51-73.

72 Page, Bartels and Seawright, "Democracy": 63. 
climate change action, and economic aid abroad are professionals - specifically, doctors and lawyers (for whom income rather than wealth remains important). ${ }^{73}$ Further work by Gilens and Benjamin Page has added to these findings by showing that the economic elite has a significantly higher influence on public policy than the average citizen. ${ }^{74}$ And a recent analysis by Thomas Edsall of American voters in 2015 shows that even well-paid, well-educated, upper-middle-class Democrats are conservative when it comes to redistribution. As he puts it: "These voters are repelled by a social conservatism that is anti-abortion, anti-gay rights and anti-women's rights. But they are not eager to see their taxes raised." $" 75$

This is only a rough proxy, of course, for middle-class human rights support. It suggests, however, that whether or not this elite supports civil and political rights abroad, it does not support economic and social rights domestically - quite the opposite. The affluent represent the apex of the middle class, of course: it is far wider and more diverse in its view than this picture suggests. In the UK case, for example, opinions on the suggestion by the Conservative party that Britain might withdraw from the European Court of Human Rights split almost entirely along party lines in polls (the right favors withdrawal, the liberals and the liberal-left do not). ${ }^{76}$

And this is not purely a Western phenomenon. Joshua Kurlantzick has argued, building on studies by Freedom House and others, that democracy seems to be in retreat elsewhere because the middle classes in many developing countries have taken fright at the implications of democratization for their own security, wealth, and influence ${ }^{77}$ Other analysts have seen middle-class support for authoritarian military government in Egypt in the same light. ${ }^{78}$ We might even see cash giveaways to public workers in Saudi Arabia as a way to stem support for any form of political

${ }^{73}$ Page, Bartels and Seawright, "Democracy": 65.

${ }^{74}$ Martin Gilens and Benjamin I Page, "Testing Theories of American Politics: Elites, Interest Groups, and Average Citizens," Perspectives on Politics, v. 12, no. 3 (2014): 564-81. See also Joseph E Stiglitz, The Price of Inequality (New York: WW Norton and Co, 2012).

75 Thomas B. Edsall, "The Problem with Middle-class Populism," New York Times (February 2015), at: www.nytimes.com/2015/02/04/opinion/the-problem-with-middleclass-populism.html?emc $=$ eta $1 \& \_r=0$.

${ }^{76}$ William Jordan, "Support for Tory Human Rights Plans falls along Party Lines," YouGov.UK (October 2014), at: http://yougov.co.uk/news/2014/10/08/support-toryhuman-rights-plans-falls-along-party-/.

77 Joshua Kurlantzick, Democracy in Retreat: The Revolt of the Middle Class and the Worldwide Decline of Representative Government (New Haven: Yale University Press, 2013).

${ }^{78}$ Maged Mandour, "Liberalism without Democracy: The Case of Egypt," OpenDemocracy (February 2015), at: www.opendemocracy.net/arab-awakening/maged-mandour/liberal ism-without-democracy-case-of-egypt. 
liberalization at a time of regime transition. ${ }^{79}$ More generally, Landman and Larizza have shown that income inequality correlates strongly with increased human rights abuses, particularly in terms of personal integrity rights. ${ }^{80}$

Tunisia might be one bright spot that provides a counter-example, having evolved more of a middle class under President Ben Ali's dictatorship and thereby laying some of the ground work for democracy. ${ }^{81}$ Long-term middle-class pressure was important in chipping away at the foundations of the regime before the self-immolation of Mohamed Bouazizi sparked the Arab Spring. ${ }^{82}$ Iran might be another positive case on issues such as the death penalty. ${ }^{83}$ But in major cases like China we see a compact between the wealth-creators and the state where enrichment is the price for accepting a lack of political freedom. ${ }^{84}$ And in India, middle-class support for Prime Minister Narendra Modi is allied to a degree of skepticism about the political process (linked to anger at corruption) and a renewed emphasis on a Hindu ethno-religious nationalism (contra human rights) which has emerged precisely as an antidote to the materialism that new wealth has brought. ${ }^{85}$ Best-selling analyst of inequality, Thomas Piketty, has even taken the buoyant Indian middle classes to task for their lack of concern about inequality. ${ }^{86}$

This issue lies at the root of problems within the human rights movement more widely. There is a political economy in this movement

${ }^{79}$ Ben Hubbard, "Saudi King unleashes a torrent of money as bonuses flow to the masses," New York Times (February 2015), at: www.nytimes.com/2015/02/20/world/middleeast/ saudi-king-unleashes-a-torrent-as-bonuses-flow-to-the-masses.html?emc=eta 1 .

80 Todd Landman and Marco Larizza, "Inequality and Human Rights: Who Controls What, When and How," International Studies Quarterly 53 (2009).

${ }^{81}$ On Tunisia, see, for example, Brian Klaas and Marcel Dirsus, "The Tunisia Model: Did Tunis win the Arab Spring?" Foreign Affairs (October 2014), at: www.foreignaffairs.com /articles/142290/brian-klaas-and-marcel-dirsus/the-tunisia-model.

${ }^{82}$ Eric Goldstein, "A Middle-Class Revolution," Foreign Policy (January 2011), at: www .foreignpolicy.com/articles/2011/01/18/a_middle_class_revolution.

83 Thomas Erdbrink, "Mercy and Social Media Slow the Noose in Iran," New York Times (March 2014), at: www.nytimes.com/2014/03/09/world/middleeast/mercy-and-socialmedia-slow-the-noose-in-iran.html?emc=edit_th_20140309\&nl=todaysheadlines\& nlid $=18548227 \& \_r=0$.

${ }^{84}$ On China, see Kellee Tsai, Capitalism Without Democracy: The Private Sector in Contemporary China (Ithaca: Cornell University Press, 2007) and Yang and Zhu, "Collective Apathy."

85 Christophe Jaffrelot, "Modi of the Middle Class," Carnegie Endowment for International Peace (March 2014), at: http://carnegieendowment.org/2014/03/24/modi-of-middleclass and Leela Fernandes, India's New Middle Class: Democratic Politics in an Era of Economic Reform (Minnesota: University of Minnesota Press, 2006).

${ }^{86}$ Manu Joseph, "Piketty to India's Elite: 'Learn from History,"” New York Times, December 2015, at: www.nytimes.com/2015/12/10/world/asia/thomas-pikettyinequality-india-mumbai.html?_r=0. 
all the way down that makes it hard for the priorities of the base - the mass of people at the bottom - to really affect the priorities of global campaigns. Global human rights is in many ways conservative where grass-roots human rights work is revolutionary and much more conventionally political. If the people are at the bottom, the money is still at the top.

Nevertheless, having said all of this, at least two further observations might be made about the "status quo-oriented middle class" argument and the sad outlook it predicts for narrowing inequality by genuinely embracing socioeconomic rights. First, any modern democratic society cannot sustain itself indefinitely if the majority of the people are alienated from the fruits of their labor and from access to wealth. As many Western states are currently discovering, status-quo politicians are an endangered species, with increasingly angry populations on the left and the right demanding change. This suggests that the middle classes will quite possibly be forced into greater efforts at redistribution than they might otherwise choose. ${ }^{87}$ Second, middleclass gains against the state may be hard to achieve and harder to sustain without strategic engagement and even alliance with key social interest groups and movements who bring leverage through numbers.

Indeed, these two points intersect. If the middle classes need the state to protect their wealth, having alienated other potential social allies, they will be weak bargainers when it comes to demanding the state be more accountable to them and even grant concessions. If the middle classes seek to ally with broader social forces, against the state, then they'll need to cement this alliance by embracing a more widely shared agenda that better reflects the interests of the "have-nots," including those who for reasons of identity not wealth may be marginal, as well as the "haves."

\section{$4 \quad$ On the Road to Nowhere}

There is no longer any hegemonic definition of what constitutes the content or foundational authority of human rights, I suggest, the conversation now being about diversity, variability, "multiple modernities,"

${ }^{87}$ This homogenizes the middle class far too much, obviously, especially where, as in the United States, the majority of people see themselves as middle class. I am using "middle class" as a proxy for those - urban, professional, well-salaried with a reasonably significant degree of equity wealth (e.g., in property and stocks) and a college or higher education - who comprise the core of the top, say, $10 \%$ of a society in terms of wealth profile. 
where there are various forms of being modern, not all of which are in full alignment with the benchmark standards of universal and inalienable human rights as classically conceived and politically institutionalized. ${ }^{88}$ In other words, there are no red lines that enjoy universal political support (even if they seem to enjoy a legal consensus). There is a further issue in that many of the most pressing human rights issues of our era will involve acts of private violence (e.g., domestic abuse, sex crimes) and these are not covered by international law, which remains principally about atrocity crimes of one sort or another committed by states and their officials. And as I have argued, human rights are not necessarily progressive - their firstgeneration, civil, and political variant dominates for structural (not transient) reasons over social and economic, cultural and group rights. This is a very conditional, class-specific form of liberal freedom, as Barrington Moore noted. Better, no doubt, than the alternatives glimpsed under authoritarianism, but a long way from the aspirations of many human rights advocates.

In their book The Human Rights Paradox, Steve Stern and Scott Straus see this conjunction between the universal and local as an irresolvable tension in all human rights work, each unable to escape the other. They must learn to co-exist. Rather than "eternal transcendent rights that emerge after a formative point of historical origin," Stern and Straus conceptualize rights as relational (between people, between local and global), and contextual, giving rise to "a shifting history and future of urgent fundamental rights attached to the human." 89 Mark Goodale echoes this, asking why "liberal (or neoliberal) legal and political theory should continue to prove so foundational when this political choice is no longer necessary." 90

But this elides perhaps the key problem for a more pragmatic, diverse, agile, flexible, democratic global human rights movement. Many human rights advocates, in the West and elsewhere, believe in a radical moral critique of established authorities from the perspective of individual entitlements. They have a normative commitment, not

${ }^{88}$ S. N. Eisenstadt, ed., Multiple Modernities (New Brunswick: Transaction Publishers, 2005) but also Peter J. Katzenstein, ed., Civilizations in World Politics: Plural and Pluralist Perspectives (London: Routledge, 2010).

${ }^{89}$ Steve Stern and Scott J Straus, "Embracing Paradox: Human Rights in the Global Age," in The Human Rights Paradox: Universality and Its Discontents, Stern and Straus (eds.) (Madison: University of Wisconsin Press, 2014), pp. 10-11.

${ }^{90}$ Mark Goodale, Surrendering to Utopia: An Anthropology of Human Rights (Stanford: Stanford University Press, 2009), p. 10. See also Sonia Harris-Short, "International Human Rights Law: Imperialist, Inept and Ineffective? Cultural Relativism and the UN Convention on the Rights of the Child, Human Rights Quarterly, vol. 25 no. 1 (2003), p. 181. 
a career. ${ }^{91}$ Moreover, they hold to a version of the "Orientalist" map that separates the world into areas of concern about rights (e.g., for LGBT rights, Africa, and the Middle East), and areas where those rights are better observed (principally in the West and a few other states and societies). Where some are skeptical about the lessons to be drawn from the Pew Center's findings on anti-homosexual prejudice, most human rights advocates would see this map as an accurate reflection of where the needs are greatest in terms of LGBT activism (as one example). ${ }^{92}$

In other words, there is a core claim about individual autonomy and choice that in principle limits the scope of any pragmatic reorientation. Means might be adaptable, but not ends. To make the journey openended is to put human rights on the road to nowhere (that is, to "nowhere in particular"). But most human rights activists know the destination at which they are aiming; they just puzzle and struggle over how to get there. The power of these rights is in their clear and unequivocal codification. They are timeless principles. "Freedom" and "justice," as I argued at the outset, can accommodate diverse forms of realization. But human rights really do have some uncrossable barriers (red lines, individual trump cards, vetoes) beyond which they can no longer be called rights in a meaningful way. For advocates, human rights are on the road to somewhere - e.g., universal gender equality. If this isn't where Stern and Straus's negotiated tension ends up then we cannot be, for global advocates, talking about human rights any more. But this inflexibility about ends makes human rights politically inept, even counterproductive, as humanitarians have discovered. ${ }^{93}$

If global norms do get retrenched, this will reverberate through the human rights ecosystem. When China says human rights are not a global norm, or are colonial impositions, or Russia says your interpretation of human rights is not the same as ours but ours is just as valid, there is no option but to listen. Add to this the constituency of social conservatives in all societies, the West and non-West, mobilized and organized to block change even if they cannot prevail, and the angry leftists who see their lives blighted by globalization, and you have a recipe for a stalled human rights revolution at best, and for rollback

${ }^{91}$ Although much more could be said about this: see Stephen Hopgood, The Endtimes of Human Rights (Ithaca: Cornell University Press, 2013), chap. 5.

92 Rao, "The Locations of Homophobia," pp. 169-171 and the Pew Research Center Global Attitudes Project, "The Global Divide on Homosexuality," (June 2013), at: www .pewglobal.org/2013/06/04/the-global-divide-on-homosexuality/

${ }^{93}$ Marie-Pierre Allié, "Introduction: Acting at Any Price?" in Claire Magone, Michaël Neuman, and Fabrice Weissman, eds., Humanitarian Negotiations Revealed: The MSF Experience (London: Hurst/MSF, 2011), pp. 1-11. 
at worst. Populist leaders have put aspects of both the left and right critiques together to challenge liberal norms at the national level throughout the West.

One response to these anxieties has been to forge ahead, increasing the number of permanent institutions that support human rights (on the principle that even if the language is in question, the institutions, once established, are harder to disassemble and will have positive long-term effects). This is one way to see the proposed Convention on Crimes Against Humanity - as a capstone to complete the global architecture of human rights law. And it may well pass, with reservations (if the United States is to join) or without (if great powers are not to be allowed to dictate the terms of the treaty). But what difference will it make to the everyday lives of billions of people living under authoritarian rule or suffering from endemic forms of private violence, police torture, brutality, or systematic discrimination?

This rapidly transforming world can be characterized as neoWestphalian. ${ }^{94}$ Global trade and finance, essential elements of the affluence of growing powers such as China, as well as collective security concerns about transport, energy, and weapons, create shared interests in the preservation of international order. In this sense, India, China, Brazil, and perhaps even Russia have a stake in the continuation of the system (as Ikenberry argues). But there is no evidence they want to expand the hierarchical system of rules and norms centered around human rights and international justice. Great powers will break their own rules when it really matters to them. And international law will always have an element of "indeterminacy" such that competent arguments both for and against certain courses of action can be made. ${ }^{95}$ From this it is but a short step to competing and even new norms. There may be what has been called a "structural bias" in favor of the liberal settlement, but it is precisely the survival of the preconditions for that bias that I am questioning. Or rather, it will function within zones of relative peace, security and justice, and not for their borderlands, which will remain zones of conflict, poverty and injustice. These divisions

${ }^{94}$ My understanding of NeoWestphalia is less homogeneity, less integration, more competition, and no universal norms. Jan Zielonka uses the term "neo-Westphalian" in exactly the opposite sense in the context of EU enlargement; see Jan Zielonka, "Enlargement and the Finality of European Integration," Harvard Jean Monnet Working Paper, symposium in response to Joschka Fischer, 2000, and Europe as Empire: The Nature of the Enlarged European Union (Oxford: Oxford University Press, 2007).

${ }^{95}$ Martti Koskenniemi, From Apology to Utopia, reissue with new epilogue (Cambridge: Cambridge University Press, 2005); David Kennedy, A World of Struggle: How Power, Law, and Expertise Shape Global Political Economy (Princeton: Princeton University Press, 2016). 
exist within societies as well as between them. What we might have to give up, for a generation at least, is the idea that the two zones will be fused into one single glorious, universal, and liberal whole. Embracing the road to nowhere may seem like a step forward in that the newly multipolar world must be more about diversity and conversation and less about uniformity and diktat. But this may also prove to be an illusion, leaving just the lucky few still traveling the road to somewhere (most probably a gated community in an affluent suburb). 